\title{
NORTHERN ORIOLE
}

\author{
JEAN BANCROFT, 306-200 Tuxedo Avenue, Winnipeg, Manitoba. R3P OR3
}

The arrival in mid-May of the male Northern (Baltimore) Oriole at Whytewold (on the southwest corner of Lake Winnipeg) is made known by its loud and clear liquid call of peter-peter-peter and its flaming orange and black plumage.

A few days later the female, in more subdued tones arrives and courtship begins. As soon as I am aware of their joyful presence I hang two orange halves in basket-like fashion from the lower branch of a tree in order to attract them to our property. In anticipation of nest building I scatter about the yard $15-\mathrm{cm}$ lengths of white string, separated twine, bits of colored yarn and clumps of fluffy cotton from the clothes dryer.

It is generally the first week in June when construction of the nest begins. Then comes the exciting time - watching to see which female picks up what and where she will fly. I have never at any time seen the male pick up any material, nor help construct the nest. In fact, the female does not permit him to do so; she is very aggressive and is determined to build the nest entirely by herself. ${ }^{2}$ However Liz Roley reported that a male Baltimore picked up materials and "delivered them to the weaver" at the nesting site. ${ }^{7}$ Various observers note that the female does all the building, while the male keeps her close company and gives his chatter-call from a branch close by. ${ }^{6} 8$

In 1977 when I first scattered materials for nest building one female picked up only bits of cotton fluff. ${ }^{1}$ On one occasion a female pulled out one long human hair from a small clump of fluff on the lawn and flew off with it to weave it into the nest. By 1981 there was a noticeable increase in the use of white string and some colored yarn, except for red. ${ }^{3}$
A few years ago an unusual cup-like nest was built in an oak tree, woven mainly of very narrow plastic strips and lined with fibrous material. ${ }^{1}$ In 1984 another variation was observed in nest construction. One female picked up various colors, including red, and flew to the top of one of our old oak trees where she constructed a "patchwork" nest. This particular female had plumage coloration similar to a Bullock's Oriole (since Bullock's and Baltimore orioles hybridize freely they are now classed as one species, the Northern Oriole).

In our area the Northern Oriole is attracted mainly to tall aspens which are just commencing to burst forth in fresh green but, among the many nests I have observed, a few have been built in Oak or Manitoba Maple trees. The nest is usually an intricately woven hanging pouch about 9 to $20 \mathrm{~cm}$ deep and anywhere from 2 to $18 \mathrm{~m}$ above the ground. ${ }^{5}$ It is fascinating to watch the female use her bill like a darning needle. First she weaves a single fibre in and out and fastens it securely to her chosen twig(s). The nest stands out as a work of architectural art in the bird world. It may take from 4.5 to 8 days to complete the nest. It is entered from the top. ${ }^{5}$ The upper part is somewhat transparent; the bottom is a thick mass and is lined with fine grasses and cotton fluff. The nest is made to withstand the assaults of fierce wind and rain. In many instances old nests remain on a tree for several years.

This year the nest most closely observed was in a Manitoba Maple in a small clump of mixed woods between a road and a cottage. On 4 June 1984 the female oriole was seen weaving a nest in an overhanging bough $3 \mathrm{~m}$ from the ground. On 9 June the nest appeared to be completed. It was constructed mainly of plant fibres and a few 
pieces of white string, was pensile, and at least $12.5 \mathrm{~cm}$ deep. Two days later the female commenced to sit; the male was singing close by. On 15 June when I ventured close to the nest site the male gave his warning call. On 23 June I observed the female fly off the nest; the male flew close to it to keep watch, but did not enter it. The female then returned. Only the female incubated. I was not able to count the eggs but literature reports indicate clutch size is 4-6 and that the incubation period is $12-14$ days. ${ }^{5}$

On 24 June the male flew to the nest with a spider in his beak and fed the nestlings. A few minutes later the female took a turn, and then brooded. Neither bird ever flew directly to the nest; they were very cautious and if the call of another species was heard close by either male or female would perch for several minutes a few feet from the nest and when danger was past, would work their way among the leaves to the nest to feed the nestlings.

I continued visiting the nest site frequently but it was not until 30 June when both male and female were making trips with insects to the nest, that I was able to see one tiny beak through the thin upper part of the nest. On 2 July two tiny necks stretched up. Two days later there was much movement in the nest and I saw three nestlings. Early the next day the female sang before she went to the nest with a cankerworm. ${ }^{8}$

Fishflies (mayflies) were now in abundance, so that food was plentiful. On 5 July two young flapped their wings and then moved out of the nest. At that time three young necks stretched up for food. It was now apparent that there were five young.

There was continuous activity at the nest site; numerous calls came from young and adults on 6 July. In fact, during my three visits that day, the young orioles never stopped calling, unless warned by the adults that danger was near. Early the next day all was quiet - the nest was empty!
During the first 2 weeks in July, throughout the neighborhood the air becomes alive with the repetitive calls of young orioles - tee-dee-dee-tee-dee-dee. They seek refuge in bushes and treed areas, where they are fed by the parents until they can fend for themselves.

The Northern Oriole is one of our most colorful and valuable birds, due to its huge consumption of all kinds of insects. In this area it also eats Saskatoon berries and has been seen taking nectar at hummingbird feeders.

The Whytewold region on Lake Winnipeg appears to be a favorite breeding ground for the Northern Oriole. We feel very fortunate to have such large numbers of this very attractive species return every summer!

' BANCROFT, J. 1978. Variations in bird nesting habits. Blue Jay 36 (2):120.

2 BANCROFT, J. 1978. "Talk about Women's Lib!' Purple Martin News, Griggsville, III., U.S.A. (December 1978).

3 BANCROFT, J. 1982. Further observations of variations in bird nesting habits. Blue Jay 40(2):126-127.

${ }^{4}$ BENT, A.C. 1960. Bent's life histories of North American birds. Vol. 2 H.H. Collins, Jr., Ed. Harper Bros., N.Y. 374 pp.

${ }^{5}$ HARRISON, H.H. 1975. A field guide to birds' nests in the United States east of the Mississippi River. Houghton Mifflin, Boston, 257 pp.

${ }^{6}$ ROBERTS, T.S. 1932. Birds of Minnesota Vol. 2 University of Minnesota Press, Minniapolis. $821 \mathrm{pp}$.

7 ROLEY, L. 1983. Nature Notes. The Leader-Post, 25 June 1983. Regina, Saskatchewan.

${ }^{8}$ STOKES, D.W. \& L.Q. STOKES. 1983. A guide to bird behavior. Vol. 2 Little Brown \& Co., Boston and Toronto. 334 pp.

${ }^{9}$ UDVARDY, M.D.F. 1977. The Audubon Society Field Guide to North American birds, western region. A.A. Knopf, N.Y. 853 pp. 